\title{
El realismo en «El negro», de Salarrué ${ }^{1}$
}

\section{(Realism in "El negro", by Salarrué)}

\author{
Marta Sánchez Salva2 \\ Universidad de Bergen, Noruega
}

\begin{abstract}
RESUMEN
Se rebaten dos tipos de críticas sobre Cuentos de barro (1933), de Salarrué: se cuestionan interpretaciones que identifican a los personajes con los indígenas y los negros reales de El Salvador en las décadas de 1920 y 1930; por otra parte, se disputan las críticas académicas que, a pesar de reconocer el ingrediente inventivo en las representaciones de los personajes, califican la ficción de un acto engañoso. Con el análisis de «El negro», con atención en el discurso metafórico, el realismo de Salarrué es más complejo que el realismo concebido como una copia fiel del mundo real.
\end{abstract}

\section{ÁBSTRACT}

The study refutes two types of criticism about Cuentos de barro (1933), by Salarrué. It questions interpretations identifying the characters with real indigenous and black people in El Salvador in the 1920s and 1930s. Moreover, it argues against academic criticism which, in spite of acknowledging the non-realistic traits ofthe characters, describes the fiction as misleading. Through the analysis of "El negro", with attention to the metaphoric discourse, Salarrué's realism is viewed as more complex than realism conceived ofas a faithful copy ofthe real world.

Palabras clave: literatura centroamericana, Cuentos de barro, Salarrué, El Salvador, grotesco, realismo literario

1 Recibido: 17 de noviembre de 2013; aceptado: 20 de enero de 2014. 2

Correo electrónico: martasalva77@gmail.com 
Keywords: Central American literature, Cuentos de barro, Salarrué, El Salvador, grotesque, literary realism

\section{Introducción: Simulacro en Cuentos de barro}

Cuentos de barro (1933), de Salvador Salazar Arrué (Salarrué), son generalmente identificados con lo salvadoreño. Esto se entrevé en el hecho de ser considerada una de las obras más emblemáticas de la literatura regionalista de El Salvador y en las críticas que la definen como representativa de la sociedad rural salvadoreña. Son relatos que incorporan elementos asociados a lo autóctono: descripciones de una fauna y una flora presentes en la región centroamericana, referencias a leyendas, costumbres y situaciones cotidianas fácilmente reconocibles por el lector salvadoreño, además de un lenguaje que incluye, entre otros aspectos, la oralidad de un español rural salvadoreño y vocablos de la lengua indígena náhuat3.

La percepción de Cuentos de barro como reproducción de la realidad del campesino salvadoreño se ve reforzada con la clasificación dicotómica que la crítica literaria hace de la obra de Salarrué: una vertiente regionalista, folclórica o vernácula, y otra cosmopolita

o universalista4. La narrativa fantástica incluida en esta última se contrapone al realismo de Cuentos de barro con el efecto de relegar a una literatura costumbrista incapaz de contener elementos fantásticos.

Si bien toda ficción es ficción, como expresa el profesor George Levine5, las críticas que identifican a los personajes de Cuentos de barro con el indígena salvadoreño promueven la idea de la literatura

3 Lengua pipil hablada en El Salvador, diferente del náhuatl de los mexicas; ambas pertenecen a la familia uta-azteca. 4 Véase Javier De Navascués, «Las corrientes narrativas (11)», Felipe Pedraza Jiménez ( ed.), Manual de literatura hispanoamericana: las vanguardias (Pamplona: Cenlit Ediciones, 2002) 401-566; Juana Martínez Gómez, «Tres aproximaciones al cuento salvadoreño contemporáneo», Anales de Literatura Hispanoamericana 21 (1992) 203-214; y Sergio Ramírez, «Prólogo», Salarrué, El ángel del espejo y otros relatos (Caracas: BibliotecaAyacucho, 1985) IX-XXV. 5 George Levine, «Realism Reconsidered», M. J. Hoffinan y P.D. Murphy (eds.), Essentials ofthe 
como una copia de la vida: «el personaje de Cuentos de barro es el indio de Izalco»6, «[Salarrué] retrata a los campesinos salvadoreños en su dimensión espiritual»7, «a collection of simple narratives about the !zaleo Indians in Sonsonate province»8, «The voice ofthe Pipil»9. Es como si el peso de tales enunciados fuera capaz de convertir en verdadero lo verosímil.

Una transmutación semejante se da en la que suele llamarse la invención de la identidad nacional. El historiador Carlos Gregorio López Bemal1 ${ }^{\circ}$ advierte del carácter ficticio del «alma nacional» salvadoreña. Es un término que denota lo autóctono [verdadero] pero en realidad es una reinvención [ verosímil] de la tradición indígena llevada a cabo por una clase media criolla (véase p. ej. Roque Baldovinos, 2011b; Lara Martínez, 2007a, 2007b, 2007c) ${ }_{11}$. En su tarea de recuperación de la memoria histórica de El Salvador, escribe el salvadoreño Rafael Lara Martínez:

Al legado de los clásicos, recurrimos al imaginar el rescate de la diversidad étnica nacional. Aseguramos que Salarrué recobra vivencias indígenas [ ...] Parecería que nos bastara evocar el canon artístico

6 Ramírez, XVI. 7 Pedro Shimose, Historia de la literatura latinoamericana (Madrid: Editorial Playor, 1989) 259. 8 Nicasio Urbina, «Salarrué», Daniel Balderston y Mike González (eds.), Encyclopedia ofLatin

American and Caribbean Literature 1900-2003 (Londres: Routledge, 2004) 520.

9 Sugerente título que encabeza el texto de la contraportada de la traducción inglesa de Cuentos de barro. Ver Carro! F. Coates, «The Voice ofthe Pipil», contraportada de Tales ofClay (Cuentos de barro). Una traducción anotada y bilingüe de Cuentos de barro (San Salvador: Editorial Universidad Don Bosco, 2011 ).

10 Carlos Gregorio López Berna!, «El Salvador, 1811-2011: los avatares de la nación y los nacionalismos», VV.AA., El Salvador: Historia mínima (San Salvador: Editorial Universitaria, 2011) 138. 11 Ricardo Roque Baldovinos. 2011. «Poéticas del despojo: Mestizaje y memoria en la invención de la nación». academia.edu. Web. 8 oct. 2011. <http://www.academia.edu/263845/_po\%C3\%A9tica_del_ despojo_>; Rafael Lara Martínez. 2007a. «"El croar de un sapo" María de Baratta y la invención del "indio" salvadoreño». Elfaro.net. Web. 8 ago. 2012. <http ://archivo.elfaro.net/Secciones/ opinion/200703 26/ opinion6 _ 200703 26.asp»; Rafael Lara Martínez. 2007b. «"Hombres de bronce" "Mujeres urracas" Ambrogi Invención del terruño». Elfaro.net. Web. 8 ago. 2012. <http://archivo.elfaro.net/secciones/0pinion/20070709/opinion6_20070709.asp>; y Rafael Lara Martínez. 2007c. «Indigenismo en pintura Falso falsificadorn. Elfaro.net. Web. 8 ago. 2012. <http ://archivo .elfaro .net/Secciones/ opinion/20060828/ opinion4_ 20060828 .asp>. 
y literario nacional producción intelectual citadina para comprender el contenido de culturas campesinas y regionales salvadoreñas 12 .

Parece existir un fenómeno que lleva a no distinguir la copia del original, de ahí que Lara Martínez califique Cuentos de barro como «la obra cumbre del simulacro campesino»13. Ricardo Roque Baldovinos, por su parte, destaca el carácter inventivo de Cuentos de barro al recordarle al lector que no se halla frente a un cuadro de costumbres sino ante «una utopía de redención nacional a través del reencantamiento de la prosa de la vida moderna por obra de un pasado indígena reinventado artísticamente»14. Estas advertencias informan de la tendencia existente a considerar Cuentos de barro una imitación de la vida rural salvadoreña.

Esta confusión valdría si el lector asume que Salarrué escribía con la intención de retratar fielmente la realidad salvadoreña de las décadas de 1920 y 1930. Menos comprensible resulta, sin embargo, que valoraciones académicas que llaman la atención sobre esta confusión también vean la intencionalidad autorial de Cuentos de barro como copia del mundo indígena. Sucede entonces que se recrimina a Salarrué que dé gato por liebre con sus muñecos hechos de barro criollo pero de apariencia india o mestiza. Para Ileana Rodríguez, Cuentos de barro es «una falsificación sin límites del mundo rural»15. En cuanto a otras obras del autor hasta cierto punto también aplicable

12 Rafael Lara Martínez, «Introducción general», Leonhard Schultze Jena, Mitos en la lengua materna de los Pipiles de /zaleo en El Salvador (San Salvador: Editorial Universidad Don Bosco, 2014) I.

13 Rafael Lara Martínez, «Prólogo», Nelson López Rojas, tr. Tales ofClay (Cuentos de barro). Una traducción anotada y bilingüe de Cuentos de barro. Por Salarrué (San Salvador: Editorial Universidad Don Bosco, 2011) 14.

14 Ricardo Roque Baldovinos. (2011a). «Cuentos de barro, cultura popular y reinvención nacional». academia.edu. Web. 10 nov. 2014. 〈http://www.academia.edu/915258/ Salarru\%C3\%A9 _ cultura_popular_y_reinvenci\%C3\%B3n_nacional>.

15 Alude a un comentario de Sergio Ramírez sobre la literatura vernácula centroamericana (1985: XVI). Ver Ileana Rodríguez. «Convergencias disciplinarias y solidaridades letradas translocales: "Indios Modernos" y literatura costumbrista: el caso de Salarrué». Istmo: Revista virtual de estudios literarios y culturales centroamericanos 8 (2004). Web. 10 nov. 2014. <http://istmo.denison. edu/n08/articulos/convergencias.html>. 
a Cuentos de barro, Rafael Lara Martínez tilda de «fraude» la imaginación poética de Salarrué:

La introspección poética sustituiría la investigación científica. La memoria personal reemplazaría los archivos nacionales. El rostro del otro se corresponde a la imagen que el "yo astral" posee de él. El lagos indígena lo "proyecta" la actividad espiritual del artista en su trascendencia creadora 16 .

Cabe preguntar si estas críticas niegan o desconocen, la licencia poética del escritor literario. Se hace necesario volver al prólogo de Cuentos de barro para aportar evidencia de la libertad que el autor se toma en modelar sus muñecos de barro17. En «Tranquera» el autor se nos presenta como un demiurgo que sin engaños nos cuenta cómo ha creado su universo de barro a partir de él mismo: «del barro del alma están hechos; y donde se sacó el material un hoyito queda [ ... ]»18• No tiene fundamento calificar de engañosa la mímesis que Salarrué pueda sugerir cuando escribe «con las manos untadas de realismo» (8). El platonismo que subyace las críticas de Lara Martínez y de Rodríguez les lleva a concebir la imitación como un acto fraudulento que ofrece una representación falsa de la realidad. La declaración del autor en el prólogo, sin embargo, contiene una visión del realismo, o del arte, como una empresa honestamente deshonesta $19 \cdot$

16 Rafael Lara Martínez. 2013. «Salarrué: El otro en lo mismo= "El indio adentro"». Elfaro.net. Web 2 oct. 2014. <http://www.elfaro.net/es/201307/el_agora/12813/Salarru\%C3\%A9-El-otro-enlo-mismo-=-\%E2\%80\%9CE1-indio-adentro\%E2\%80\%9D.htm>.

17 En su prioridad de lo histórico frente a lo literario, estas críticas no manejan la distinción entre «autor real», «autor implícito» y «narrador», y por lo tanto, identifican el autor (incluso a veces, el narrador) de Cuentos de barro con la persona de Salarrué. Queriendo confrontar las críticas en los mismos términos, el presente artículo no diferenciará el «autor real» del «autor implícito».

18 Salarrué, Cuentos de barro (San Salvador: Dirección General de Publicaciones del Ministerio de Educación, 1962) 9. En adelante, las referencias de esta obra se incluyen entre paréntesis. 19 Así describe Potolsky la redefinición de la crítica de la mimesis de Platón que encuentra en la poética de Osear Wilde. Ver Matthew Potolsky, Mimesis (Nueva York: Routledge, 2006) 109. 


\section{Utopía en Cuentos de barro}

Un análisis interpretativo ya no revela un reflejo del mundo salvadoreño, sino una proyección de ese mundo hacia otro en estado de cambio. Este aspecto utópico en Cuentos de barro suele ser ignorado o malinterpretado por la crítica, concretamente cuando se analiza la concepción de la identidad del indio y del negro implícita en los relatos.

Para Rodríguez el modo con el que Salarrué percibe al indígena es un reflejo de su deseo positivista de re formular la identidad del indio para que coincida con la del criollo. En su análisis de «La botija», la pereza representa el atraso del indio en la mente de Salarrué. La metamorfosis del holgazán José Pashaca en un trabajador inagotable consiste, según su lectura, en la realización del «sueño positivista: si sólo pudiese transformar las etnias en trabajadores, otro gallo les cantaría, el atraso sería remediable y, la modernidad periférica, simple modemidad $2_{20}$. Es decir, el indio Pashaca acaba disciplinado por el autor en el quehacer capitalista, quien impone de esta manera su sentido de identidad al indígena. Esta interpretación, además de resultar incorrecta por no atender a los aspectos del texto que rechazan la tesis del cuento de barro como transmisor de la ética capitalista21, pasa por alto el transcendentalismo del relato.

En el momento en que Rodríguez entiende que Pashaca nunca estuvo consciente de su transformación en un trabajador incansable 22 , el relato revela un proceso más complejo. La falta de atención a la simbología del texto dificulta la comprensión del mensaje. Con ingenio y sutilmente, en forma de presagios e insinuaciones, Salarrué va dejando indicios del destino cósmico de José Pashaca. La subalternidad del personaje al trabajar por fuerza no es el producto final de

20 Rodriguez, 22.

21 Véanse mis lecturas de «La botija» $\mathrm{y}$ «De caza» para entrever la concepción de Salarrué sobre el valor económico. Marta Sánchez Salva. El «regionalismo» en Cuentos de barro de Salvador Salazar Arrué (Salarrué). Tesis. Universitetet i Bergen. 2014. Impreso. 22

Evocando el concepto reduccionista de falsa conciencia. 
la metamorfosis. Al convertirse finalmente en el árbol cósmico, José Pashaca se hace dueño y creador de su propio destino. Su acto de resistencia se produce en el plano espiritual, y para percibirlo se requiere una lectura atenta a lo metafórico. En otras palabras, es posible leer «La botija» de manera realista, concentrándose en las relaciones de producción y el estereotipo del indio holgazán; sin embargo, de este modo el lector no captará el empoderamiento de José Pashaca, que lo lleva a traspasar los límites de lo irrealizable.

Ahora bien, siguiendo la lógica de Rodríguez, es lícito insistir en que el cambio espiritual del protagonista no deja de ser un modo patemalista de empoderar al indígena, lo que, al fin y al cabo, no es más que la mirada teosófica personal que Salarrué impone a la espiritualidad del indio. Desde un punto de vista histórico, Cuentos de barro es una creación que aplica las fórmulas del mestizaje y la teosofia en boga durante las primeras décadas del siglo $\mathrm{xx}$ para proyectar una idea de universalidad. Evidentemente, mediante esta mirada universalista se produce una selección y fusión de los elementos creídos necesarios para que los personajes puedan cumplir el destino espiritual que el autor les ha reservado. Es el escritor blanco quien transmuta la diversidad étnica de su contexto social (real) en el indio y el negro (ficticios) en estado de mestizaje racial y espiritual irreversible 23 . En este sentido, la labor de Salarrué supone el despojo simbólico del indio y del negro. No obstante, de ello no se puede deducir que se trate de un acto de engaño o una falsificación de la verdad. Más bien, lo que Salarrué hace es utilizar la licencia poética del creador literario que «le permite crear datos en los silencios de la historia o recomponerlos en función de las

23 En la década de 1920, José Vasconcelos habla del rol del hombre blanco en la tarea trascendental de fundir todas las razas y culturas en una raza universal. En su visión de la historia, cada raza tiene una misión que cumplir antes de desaparecer y dar paso a una nueva. Este determinismo racial le lleva a concluir que al indio ahora ya bien fusionado con el español no le queda otra opción que seguir el camino modernizador dirigido por el blanco, quien a su vez «buscará progreso y redención posterior en el alma de sus hermanos de las otras castas, y se confundirá y se perfeccionará en cada una de las variedades superiores de la especie [ ... ]». Se trata de un progreso espiritual que apuesta por la unidad de las especies. Ver José Vasconcelos, The Cosmic Race (La raza cósmica). A Bilingual Edition (Baltimore: The Johns Hopkins University Press, 1979) 56. 
verdades trascendentes, aunque no apoyadas por datos, que vislumbra el autor en los intersticios de la historia»24. De esta manera Salarrué recompone y crea datos en función de $s u$ verdad trascendente. La utopía que subyace a esta empresa aflora en los cuentos en forma de ironías y paradojas, conseguidas en muchos casos recurriendo a imágenes visionarias. Todas ellas son herramientas retóricas y metodológicas que apuntan, directa o indirectamente, a la idea de un cambio epistemológico deseable, unos nuevos lentes con los que mirar la realidad. Donde más explícitamente encontramos rastro de ello es en «La botija»y «El negro», relatos que abren y cierran Cuentos de barro. Ambos textos tocan el tema del mestizaje comentado anteriormente, aunque es en «El negro» en que mejor se pueden ver los aspectos tanto raciales como espirituales.

\section{La raza en términos fisiológicos: "El negro" de colores}

Si se presta atención a la paleta usada para pintar a Nayo, el protagonista del cuento de barro «El negro», pone de manifiesto la relatividad de su negrura. Su piel es descrita con matices «morados», «a ratos» con «tomasombras azules, de un azulón empavonado de revolver» (177), y con «un poco la color bronceada de la piel» del indio «que no alcanzaba a velar su estructura grosera, amasada con brea y no con barro» (178). En la superficie, pues, Nayo es negro como un revólver aunque a ratos se vislumbran tonos morados, azules y marrones. A primera vista, esta gama y superposición de colores puede sugerir dos aspectos del negro.

Por una parte, su negrura azulada identificada con un arma puede ser interpretada como amenazadora. $\mathrm{N}$ ayo había llegado «dende lejos» (177), «era de porái... : de un porái dudoso, mezcla de Honduras y Berlice, Chiquimula y Bluefiles de la Costelnorte» (178). La duda sobre

24 Magda Zavala. «Historizar las literaturas centroamericanas». Istmo: Revista virtual de estudios literarios y culturales centroamericanos 8 (2004). Web. 10 nov. 2014. <http://istmo.denison.edu/ n08/proyectos/historizar.html>. 
su origen traza una línea entre lo conocido y lo desconocido, entre un nosotros y un él. La historiadora Patricia Alvarenga Venutolo señala acertadamente cómo esta descripción refleja la relación del negro con la historia de El Salvador y Centroamérica: «Esa procedencia dudosa expresa brillantemente la 'ilegitimidad' negra en las construcciones nacionales centroamericanas $2_{25}$. No obstante, este poder desconocido del negro, y por tanto temido, se disuelve en la familiaridad que pueda evocar su marrón de indio. El mestizaje se hace evidente en su pie «de indio», «achatado, caitudo26, raizoso y sin uñas» (178). Por lo tanto, esa «mezcla» de Honduras, Belice, Guatemala y Nicaragua también puede indicar proximidad.

La señal de mestizaje con el barro indio, a su vez, parece deshacerse al identificar la morfología del negro con la oscuridad de la brea. Se insiste en recordar al lector la idea de un origen y de posteriores recubrimientos. Tanto el «empavonado»27 de su azul como ese bronceado que no logra «velar su estructura grosera» sugieren capas embellecedoras de un interior tosco. De esto se desprende, como bien comentaAlvarenga 28, una concepción jerárquica de los grupos humanos basada en valoraciones éticas y estéticas del cuerpo. Si en la piel bronceada del indígena se halla belleza, en la del negro habitan rastros de una animalidad todavía en evolución. En este sentido se podría inscribir a Salarrué en la corriente de intelectuales de la época, como el mexicano José Vasconcelos, para quien el negro proviene de una de las estirpes más feas: «[ ... ] en unas cuantas décadas de eugenesia estética podría desaparecer el negro junto con los tipos que el libre instinto de hermosura vaya señalando como fundamentalmente recesivos e

25 Patricia Alvarenga Venutolo, «Sexualidad, corporalidad y etnia en la narrativa centroamericana de la primera mitad del siglo xx», Valeria Grinberg Play Ricardo Roque Baldovinos ( eds. ), Tensiones de la modernidad: del modernismo al realismo (Guatemala: F\&G Editores, 2009) 359. 26 Con caite. Sandalia de cuero. 27 pavonar. Dar pavón al hierro o al acero. pavón. Capa superficial de óxido abrillantado, de color

azulado, negro o café, con que se cubren las piezas de acero para mejorar su aspecto y evitar su corrosión. 28 Alvarenga

Venutolo, 360. 
indignos, por lo mismo, de perpetuación»29. Concluir, sin embargo, que existen paralelismos entre el pensamiento de Vasconcelos y el de Salarrué resulta demasiado sencillo. Es necesario seguir escrutando el texto para descubrir el juego del autor con las expectativas del lector del primer tercio del siglo xx.

La animalidad del negro se insinúa en diversas ocasiones. $\mathrm{N}$ ayo tiene «desteñidas las palmas de las manos, como en los monos» (177), tiene <<paletiya» en lugar de espalda (178), y es alegre «como perro que mueve el rabo» (179). Tal como Alvarengaso advierte, la inferioridad del negro es expresada recurriendo a la parodia, aunque en los rasgos animalescos la historiadora ve simplemente la finalidad de causar risa en el lector. Cuando comenta que con «la misma naturalidad con que el narrador se identifica con los personajes, se distancia de ellos, estableciendo una relación ambivalente entre lo trágico, lo paródico y lo irónico»31, no llega a asociar esta técnica de distanciamiento con la categoría estética de lo grotesco. Al pasar por alto la función del arte grotesco en revelar el absurdo del mundo, la crítica de Alvarenga se limita a denunciar la dominación del que se ríe sobre una «otredad distante» 32 .

$\mathrm{El}$ hecho de que los aspectos grotescos de $\mathrm{N}$ ayo puedan pasar desapercibidos al lector de «El negro» puede deberse a que lo grotesco en Cuentos de barro pierde parte de su efecto al ser combinado con una compasión por esos mismos personajes deshumanizados. Sucede como con Baudelaire:

En lo grotesco de Baudelaire se mantiene una especie de dualismo romántico: incluso la marioneta tiene una dimensión de dignidad o aislamiento trágicos, se reduce lo grotesco de su condición deshumanizada, pierde su fuerza, y es absorbida finalmente por el 
sentimentalismo. Aquí lo grotesco es sólo un medio para la descripción, no un fin33.

El destino reservado para Nayo aporta un elemento trágico que lo desvía de lo grotesco. Según el crítico literario Wolfgang Kayser 34 , el destino del héroe trágico aporta sentido a un mundo absurdo y sin sentido, a diferencia de lo que ocurre en el texto grotesco, donde lo absurdo ha de permanecer sin solución. No obstante, a pesar del debilitamiento que pueda producirse en el efecto de los elementos grotescos del negro Nayo, es importante destacar su función en el texto: plasmar el sin sentido de la imagen racista del negro que prevalece en la sociedad del autor.

Además de lo animalizante, el cuerpo de Nayo presenta otros aspectos grotescos. De vegetal tiene los dientes de tubérculo y el pie de j engibre 35 , y sus rasgos orgánicos incluyen fluidos densos o viscosos como la brea de su estructura, la mantequilla de su sangre y la cuajada de su sonrisa. Las descripciones de estos dos últimos son especialmente exageradas: «la bondad le chorreaba del corazón, como el suero que escurre la bolsa de la mantequilla», y tenía una «tajada de sonrisa, blanca y temblona como la cuajada» (178). En su trabajo sobre la cultura popular medieval y del Renacimiento, el teórico literario Mijaíl Bajtín36 plantea la representación grotesca del cuerpo como un cuerpo en el acto de convertirse en otro. Lacombinación de imágenes grotescas de características corporales internas ( como la sangre, los intestinos, el corazón, etc.) y externas construye un cuerpo doble que sugiere la muerte de uno y la concepción de uno nuev037. Desde este punto de

33 Rodolfo Cardona y Anthony N. Zahareas, Visión del esperpento. Teoría y práctica en los esperpen tos de Valle-Inclán (Madrid: Editorial Castalia, 1970) 50. 34 Wolfgang Kayser, The Grotesque in Art and Literature (Nueva York: Columbia University Press,

1981) 186. 35 Las comparaciones con el mundo animal y vegetal también podrían atribuirse, como hace Sharon

Young Cherry, a la idea teosófica según la cual todos los organismos son importantes desde un punto de vista evolutivo y por lo tanto, dignos de respeto. Ver Cherry, Fantasy and Reality in Salarrué (Evanston: Northwestem University, 1977) 260. 36 Mijaíl Bajtín, Rabelais and His World (Bloomington: Indiana University Press, 1984) 317. 37 Bajtín, 318. 
vista, es posible entrever en la representación grotesca de Nayo, tanto en su aspecto exterior animal y vegetal como en su viscoso interior blanco, una intención desestabilizadora de la visión hegemónica del negro. La fusión e inversión de colores apunta a la arbitrariedad de los colores de las razas: irónicamente, el negro también es de color azul y marrón por fuera; el desteñido de sus manos deja ver el blanco que define las cavidades de su boca ( dentadura «de $j$ ícamass pelada») y de su ojo «blanco y sorprendido» (177); por dentro es blanco como la mantequilla; y «pese a su negrura» es «blanco de todas las burlas y jugarretas del blanquíозя» (178) término, este último, que muestra al indio blanco por fuera . En términos fisiológicos, el negro deja de ser negro. La tosquedad de su estructura amasada con brea no tiene por qué expresar la mirada de Salarrué sobre el negro y su imperfección corporal frente a la belleza del indígena, tal como sugiereAlavarenga 40 , sino la visión oficial del negro existente en los tiempos del autor. Mediante la descripción grotesca del negro, Salarrué ofrece no tanto un programa de mestizaje sino una percepción daltónica de los colores y las razas que subvierte la del lector de principios del siglo xx.

\section{La raza en términos relacionales: la superioridad de «El negro»}

La desfiguración de Nayo en «El negro» también ocurre en el aspecto relacional. La descripción de su actitud con los demás contiene de nuevo el rastro de una mirada que hiperboliza los estereotipos relativos al negro. Su conducta evoca tanto la inteligencia y la bondad del animal dócil como la sumisión del esclavo: Nayo reía siempre, tenía un «gesto bonachón», se humillaba «en saludos» ( 177$)$, «se reiba cascabelero $41[$ …] descupiéndose toduel» (178) y «como perro que

38 jícama. Tubérculo grande, muy blanco y azucarado. Ver Salarrué, 195. 39 blanquiyo. Alusión un poco abstracta a la indumentaria blanca de algodón ( o manta). Se usa para indicar grupos de campesinos. Ver Salarrué, 185. 40 Alvarenga Venutolo, 360. 41 cascabelero. Dicho de una persona, de poco seso y fundamento y particularmente alegre y

desenfadada. 
mueve el rabo» (179), «la bondad le chorreaba del corazón» (178). El personaje sigue siendo representado dualmente: por una parte «[n] ada podía negársele al negro Nayo», y al mismo tiempo era «blanco de todas las burlas y jugarretas del blanquío; y más de alguna vez lo dejaron sollozante[ ... ]» (178). El intento del narrador de verbalizar el porqué de este comportamiento ambivalente de los indios con Nayo se traduce en un vago «[t]enía un no sé qué que agradaba, un don de dar lástima; se sentía uno como dueño de él» (177). Más allá de estas palabras, no se explicitan en el texto otras posibles razones, de modo que el lector tiene que atender a las situaciones, al lenguaje corporal y a la simbología para comprender la naturaleza de la relación del negro con los indios.

Si al pricipio del relato el contraste entre Nayoy los indios enfatiza la posición de superioridad de los segundos, al final del cuento, es el negro quien pasa a un plano superior. La candidez de $\mathrm{N}$ ayo choca tanto con la malicia de los campesinos burlones como con las habilidades del indio Chabelo. En el plano laboral, Chabelo es «primer corralero» mientras que la posición de $\mathrm{N}$ ayo es relegada a la de «tercer corral ero» (178). Chabelo es «arriscado42», «finito de cara» $\mathrm{y}$ «miguelero 43 »con las muchachas (179). En contraposicón, el infantilismo de Nayo tenía la «cara pelotera» ( 179) y «la mirada de niño» ( 181) es la negación de la sexualidad. Otra habilidad de Chabelo es tocar su flauta «que sonaba dulce y tristosa, al gusto del sentir campesino» (179); aunque su destreza consiste en sacar provecho monetario de la flauta: «Lo llamaban los domingos y ya cobraba la vesita,juera de juerga o de velorio, de bautizo o de simple pasar» (179). Esta codicia de Chabelo difiere del desinterés material de $\mathrm{N}$ ayo en querer aprender a tocar la flauta. La flauta, en el texto, puede ser vista como el catalizador de la metamorfosis de Nayo que hasta cierto punto invertirá la relación de poder entre él y los campesinos. 
$\mathrm{Al}$ lector se le quiere hacer creer que la flauta, como en los cuentos de hadas, posee un poder mágico. Porque la fama de Chabelo no se debía a su pericia sino, tal como insinúa el narrador a través de la personificación de la flauta, a aquel «carrizo llorón» del que «[n] adie sabía cuál era el secreto», el que «[hab ]ía de tener una telita de araña por dentro, o una rendija falsa, o un chaflán carculado ... » (179). Cuando es Nayo quien toca la flauta, el instrumento es referido como «flauta apasionda44, que los hundía en la dulzura de un recordar sin recuerdos, de un retomar sin retomo», «agujero milagroso» que transmite «el fluir maravilloso de un sentimiento espeso que se cogía con las manos» (180). La introducción de la flauta como objeto mágico establece un contraste entre el carácter mágico del instrumento y la humanidad del :flautista, al mismo tiempo que busca crear una atmósfera de misterio que al final va a ser revelado.

Hacia el desenlace del relato, Chabelo, quien creía «conocer todos los secretos del carrizo» (180), empieza a dudar si el poder mágico se esconde en la flauta o en Nayo: «se quedaba pasmado, escuchando con un sí es, no es, de despecho » (180). Finalmente, Chabelo ofrece dinero a Nayo si le dice «el secreto de la flauta» (181), a lo que este responde, tras meditar «muy duro», descubriendo la verdad: «No me creya egóishto, compañero, la flauta no tiene nada: soy yo mesmo, mi tristura ... , la color ... » (181 ). A través de esta «pensada» se invierte la sencillez de Nayo transmitida en la primera parte del cuento. La malicia incial de los campesinos es irónicamente retribuida con «esa malicia» que, según Chabelo, $\mathrm{N}$ ayo le pone a la flauta (181). Si antes «se sentía uno como dueño de él» (177), ahora el poderío de Nayo «arranca el alma al cristiano como nunca» y lo somete a «la dulzura de un recordar sin recuerdos» (180). Como veremos a continuación, esta inversión de los roles del esclavo y del amo no tiene como único fin llamar la atención sobre la absurdidad de las jerarquías humanas.

44 En algunas ediciones aparece "apasionada" y por ello es dificil saber con seguridad si se trata de una errata. Aunque la tendencia del autor a crear neologismos y la insistencia en este texto de personificar la flauta me llevan a creer que "apasionda" es el término correcto. 
Es también un recurso retórico que va preparando el camino para armonizar conceptos aparentemente contradictorios.

\section{La raza en términos espirituales: la divinidad del héroe negro}

Una vez que Nayo admite ser quien propicia la dicha en los campesinos, se le transfiere la magia de la flauta. En el don de dar lástima, comentado al inicio, se puede leer ahora una habilidad de tintes divinos. La atracción que el negro ejerce sobre la lástima y la maldad de los campesinos se asemeja a la pasión del Cristo redentor. El parecido de Nayo con Jesucristo crucificado se deja ver en la siguiente imagen: «Tenía abiertos los brazos como alas rotas, sosteniendo en una mano la pluma y en la otra el bote. Miró luego al suelo empedrado [ ... ]» (181 ). En el bote está la creolina con la que está curando una ternera, un desinfectante natural cuyo color oscuro y aspecto viscoso recuerda a la brea con la que el cuerpo de Nayo está amasado. Asimismo, la densidad de sus fluidos corporales se asoma en ese «fluir maravilloso de un sentimiento espeso que se cogía con las manos» (180). Al tocar la flauta, de Nayo emana su sangre antiséptica, redentora, inmune a la maldad: «Su resentimiento era pasajero, porque la bondad le chorreaba del corazón, como el suero que escurre la bolsa de mantequilla» (178).

Hay otras señales en el texto que también apuntan a la divinidad de $\mathrm{N}$ ayo como una habilidad adquirida anteriormente a su encuentro con la flauta. Sus tonos cárdenos evocan penitencia, austeridad, preparación espiritual: «Sus veinte años, morados[ ... ] reiban siempre» (177), «su sencillez y humildad de siempre se coloreaban de austeridad y poderío mientras su labio cárdeno soplaba el agujero milagroso» (180). Sin explicitar cuál, en la primera parte del relato se menciona el destino de Nayo: «de voz enternecida por su propio destino» (178). Estos aspectos, en combinación con su edad y su franca mirada de niño que ahora se vuelven significativas, recuerdan a la concepción del héroe predestinado. En un estudio comparativo de mitologías y leyendas, 
Joseph Campbell ${ }_{45}$ distingue el héroe que alcanza su heroicidad por méritos propios como podría leerse la doma de la flauta que logra Nayo del héroe predestinado desde su nacimiento y cuya niñez milagrosa indica una encamación de un principio divino inmanente. Campbell 46 identifica dos ciclos en las hazañas del héroe: uno durante el cual el niño tiene que afrontar un largo período de oscuridad y de redención, y otro, al final del ciclo de la niñez, en el que el héroe redescubre y revela el carácer simbólico de su tarea redentora. La primera hazaña de $\mathrm{N}$ ayo está en su sencillez y su humildad, en llevar veinte años sonriendo a su «tristura», su desgracia de ser blanco de burlas por «la color» de su piel. A la malicia de los otros responde con bondad. Su segunda hazaña consiste en mostrar su verdadero carácter libertador; y lo hace transfigurado, como sucede a menudo en los mitos.

El tema de la crucifixión-resurrección aparece en el cuerpo de Nayo y en su efecto sobre los demás. En la imagen final del cuento en la que Nayo aparece con los brazos abiertos como alas rotas se alude en general al concepto de redención a través de la figura de Cristo. Al mismo tiempo, las alas dejan ver la forma concreta que toma su arte redentor. Cuando los vecinos oyen a Nayo tocar la flauta lo identifican con un pájaro: «Es meramente un zinzonte el infeliz ... » (180). La definición que el autor da de «Zinzonte o Cenzontle47》 en el vocabulario de modismos contiene una frase adversativa que parece querer prevenir al lector de dejarse llevar por meras apariencias: «Pájaro de color pardo, pero de canto dulcísimo: el ruiseñor de la América» (208).

Además del color pardo, $\mathrm{N}$ ayo y el Mimus polyglottos comparten la habilidad de imitar voces. Si el Cenzontle imita sonidos de otros animales, con su flauta $\mathrm{N}$ ayo reproduce artísticamente la superación de su tristeza, en lo que los indios se reconocen ( cabe recordar que la imagen deshumanizada del indígena también está arraigada en la 
sociedad criolla de principios del siglo xx). Como diría el protagonista de otro libro de Salarrué: la divinidad de Nayo despierta el dios que duerme en ellos 48 . Mediante su arte, los lleva a un estado redentor que los libra de su propia esclavitud. Con su canto de ruiseñor, Nayo despierta a la nueva América libre de recordar y retomar al pasado, libre de la esclavitud fisica y espiritual de sus hombres, libre, por tanto, de explorar una nueva expresión.

\section{«I negro» = el hombre $=$ el arte}

Con el uso de la paradoja, el autor ha revelado su utopía, su verdad. Primero, describe satíricamente la inferioridad que se ha atribuido al negro. Para ello acude a imágenes grotescas del cuerpo del negro y descripciones hiperbólicas de su comportamiento. Segundo, estos recursos establecen dualidades en la identidad del negro, que suponen concepciones excluyentes: el exterior del negro es de varios colores, y su interior, oscuro y blanco; su posición de sometimiento ante la malicia de los otros, y su efecto dominador sobre estos mismos, incapaces de negarle nada. La parodia de $\mathrm{N}$ ayo dista de consistir en un ejercicio impune de violencia simbólica por parte de Salarrué sobre el negro, tal como Alvarenga49 afirma, sino que se trata de un reflejo retóricamente deformado que evidencia la visión de la inferioridad del negro imperante en la sociedad salvadoreña de las primeras décadas del siglo xx. En la dualidad del personaje, la imagen hegemónica del negro es contrapuesta a su inversa para desvelar su absurdo.

En tercer lugar, Salarrué armoniza las oposiciones acerca del negro con un principio renovador que anula la distancia entre el yo y el otro: la divinidad inmanente en el hombre. Este potencial en Nayo es representado a través de su heroicidad predestinada a redimir a los

\footnotetext{
48 El personaje de don Javier dice en El Señor de la Burbuja (1927): «Dios está en mí y en cada uno de ustedes. Con la diferencia de que en ustedes duerme, apenas se percibe un hálito divino, y en mí ya está despierto y da los buenos días». Ver Salarrué, Narrativa completa I (San Salvador: Direc ción de Publicaciones e Impresos, 1999) 66. 49 Alvarenga Venutolo, 359.
} 
hombres con su arte. Del texto se desprende, además, que el carácter redentor del arte está en uno mismo y no se puede aprender simplemente imitando, tal como Chabelo cree al ofrecer dinero a $\mathrm{N}$ ayo para saber su secreto. Nayo no es un ejemplo a imitar sino un símbolo del potencial que, según el autor, posee el humano. Esta representación del negro no es, como cree Alvarenga, una afirmación del estereotipo del negro «prevaleciente aun hoy en día en el mundo occidental según el cual existen dos únicos campos en los que, quienes tienen la piel negra, son capaces de destacar: la música y el deporte $\gg 50$. No se trata del arte, aquí divino, del negro, sino del potencial creador del hombre en general. Por lo tanto, su rol simbólico tiene que ser comprendido como tal:

[T] he hero is rather a symbol to be contemplated than an example to be literally followed. The divine being is a revelation ofthe omnipotent Self, which dwells within us all. The contemplation of the life thus should be undertaken as a meditation on one's own immanent divinity, not as a prelude to precise imitation, the lesson being, not "Do thus and be good", but "Know this and be God" ${ }_{51}$.

Visto así, el rasgo que cobra mayor importancia en el físico de $\mathrm{N}$ ayo no es su color sino su piel azul de revólver. Siendo el simbolismo del color azul de su arma, y el de su impacto purificador, la liberación, lo divino, la vida creadora, el arte.

Conclusión: El realismo en Cuentos de barro

Resulta esclarecedor leer la construcción del personaje de Nayo como una metáfora del realismo en Cuentos de barro. La combinación de la visión hegemónica del negro con su imagen invertida contiene una concepción del realismo que va más allá de una simple mímesis. El negro no es tan negro como el título del cuento indica. Su pasión

50 Alvarenga Venutolo, 360. 51

Campbell, 319. 
por la flauta no consiste en un simple reflejo del estereotipo del músico negro del presente, sino en una habilidad maravillosa que simboliza una utopía realizable en el futuro. La imposibilidad por parte de Chabelo en comprar el secreto del arte de $\mathrm{N}$ ayo sugiere, también, que imitar no es lo mismo que crear.

«El negro» no es una expresión enteramente realista del negro de las décadas de 1920 y 1930, sino una creación de un personaje fantástico en su apariencia transmutada y utópico en su acción sobre los demás. $\mathrm{Si}$ el lector se acerca a este relato con esto en mente, concediéndole al autor su derecho a creer en un mundo mejor y a insinuarlo

o materializarlo con sus herramientas literarias, la confusión entre la realidad social de El Salvador y la realidad a veces creible, pero ficticia, de los hombres de barro no debería surgir. 